\title{
P-16 OIL AND GAS ASSESSMENT OF THE PROVENCE BASIN, WESTERN MEDITERRANEAN SEA
}

\section{Introduction}

The Provence basin encompasses $300,000 \mathrm{~km}^{2}$ in the western Mediterranean Sea between France, Corsica, Sardinia, Tunisia and Algeria, and the Balearic Islands. The basin is essentially unexplored because it lies in deep water $(>2,000 \mathrm{~m})$ beyond the continental shelf which limited exploration. For this reason, the basin was assessed as a single Assessment Unit within a hypothetical petroleum system by the US Geological Survey's World Petroleum Assessment 2000, a five'year program to estimate the undiscovered oil and gas potential of hydrocarbon systems in priority basins throughout the world in a 30 year forecast (1995-2025).

The basin began subsiding in late Oligocene-Early Miocene time and is believed to contain 3 to $4 \mathrm{~km}$ thickness of turbidite and pelagic sediments in the central area. The clastic sediments are overlain by the 1 to $2 \mathrm{~km}$ thick Messinian evaporites that form a hydrocarbon seal. A Pliocene-Pleistocene pelagic cover is estimated to add another $1 \mathrm{~km}$ in thickness. Attenuation and subsequent thinning of the crust beneath the basin has brought the entire sediment package into the proximity of a heat source higher in temperature relative to a normal subsidence geotherimal gradient $\left(-40\right.$ to $70^{\circ} \mathrm{C} / \mathrm{km}$, and possibly higher, versus $\sim 30^{\circ} / \mathrm{km}$ ). Sediments are estimated to be within the gas generation range, near $250^{\circ} \mathrm{C}$ : Despite this estimate of a high geothermal temperature, this basin may have substantial potential for oil around the basin margins and gas resources, the mean values of which are $388 \mathrm{MMB}$ of oil, and $51 \mathrm{TCF}$ of gas. 
The USGS assessment used the concept of the Total Petroleum System (TPS) which includes the essential elements and processes, as well as all genetically related hydrocarbons, that occur in petroleum accumulations (discovered and undiscovered) whose provenance is a pod of mature source rock. A subset of the TPS is the Assessment Unit which is a mappable volume of rock within the Total Petroleum System that encompasses petroleum fields (discovered and undiscovered) which share similar gross. geologic traits. The fields in an Assessment Unit should constitute a population that is sufficiently homogenous in terms of geology, exploration strategy, and risk so that the chosen methodology of resource assessment is applicable. A single Assessment Unit covers the Provence basin.

\section{Source Rocks}

Although this is a hypothetical Assessment Unit and the source rocks cannot be known with certainty, the primary hydrocarbon sources are expected to be Oligocene and Miocene shales. There is a possibility of some contribution from Upper Cretaceous sediments. Both oil and gas are expected to be found within this Assessment Unit.

\section{Maturation of Sediments}

A relatively young sediment pile on the order of 4 to $6 \mathrm{~km}$ thickness, with a normal geothermal gradient of about $25-30^{\circ} \mathrm{C} / \mathrm{km}$, would be sufficient to allow the maturation of organic matter to hydrocarbon. Rifting of the continental basement, bringing sediments into close proximity to a thin, attenuated crust, and closer to a high heat source accelerates maturation. The expected $250^{\circ} \mathrm{C}$ in the central part of the basin area suggests that most of the sediments are well within the range of petroleum and perhaps gas. 


\section{Migration, Reservoir Rocks, Traps and Seals}

The Messinian evaporites effectively limit vertical migration of hydrocarbons potentially generated within Oligocene and Miocene sediments. Lateral migration may be limited to only a few kilometers in the basin center while on the margins of the basin perhaps 10 to $20 \mathrm{~km}$. Reservoir rocks are expected to be Early Tertiary carbonate rock and sandstone units and Late Tertiary sandstones and turbidites. Traps would be stratigraphic, facies changes and lateral pinch-outs in sandstones; and structural, fault blocks and salt domes. Seals would primarily be Tertiary shale units, singular and within turbidites, and the Messinian evaporates.

\section{Statistical Analysis}

Defining the areal distribution of the Provence basin was the first step to completing this assessment. Then the Total Petroleum Systems and Assessment Unit(s) were outlined. The assessment would normally proceed by analysis of historic field sizes as based on the geology of the region, to arrive at sizes and numbers of fields. Undiscovered resources would then be calculated by means of a Monte Carlo simulation technique. For this hypothetical situation, a geologic analog, the Red Sea Basin province, was used to suggest comparable aspects such as geologic and tectonic history, heat flow and potential source rock types.

\section{Summary}

The Provence Basin in the western Mediterranean sea was assessed as a hypothetical petroleum system. Using a geological analog for the basin's history, heat flow and potential source rocks, the Provence basin was estimated to contain a mean undiscovered volume of petroleum of $388 \mathrm{MMB}$ of oil, 51.2 TCF of gas and 2.26 MMB of natural gas liquids. Because of the large lateral extent and thickness in excess of $3 \mathrm{~km}$, the Tertiary rocks in this basin have potential to produce oil and significant gas and natural gas liquids. 


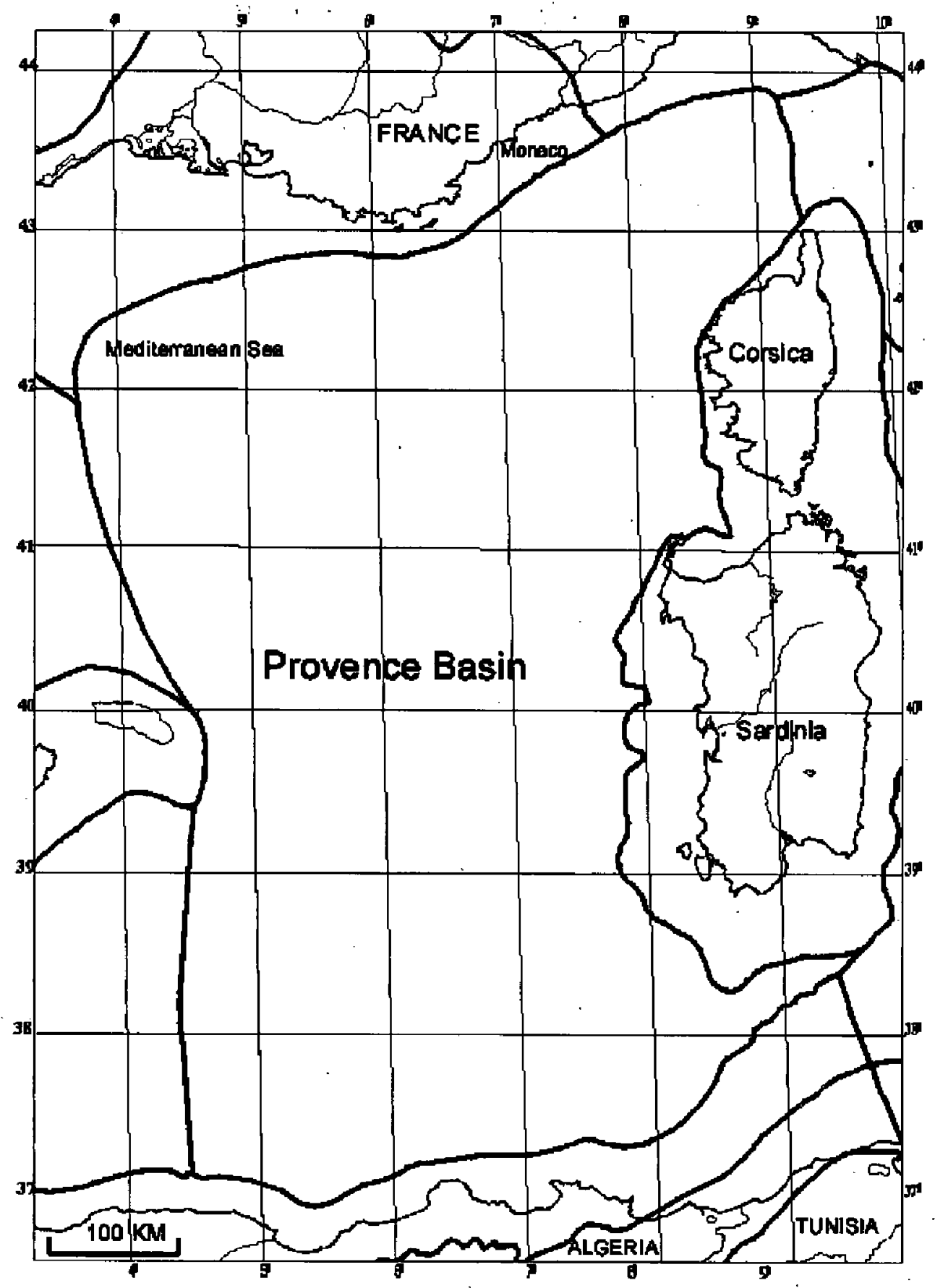

Figure 1. Provence Basin Total Petroleum System Absessment unit boundary 